\title{
The diet of feral cats at New Island, Falkland Islands, and impact on breeding seabirds
}

\author{
Rafael Matias $\cdot$ Paulo Catry
}

Received: 1 March 2007 / Revised: 16 November 2007 / Accepted: 26 November 2007 / Published online: 12 December 2007 (C) Springer-Verlag 2007

\begin{abstract}
We studied the diet of feral cats (Felis catus) on New Island, Falkland Islands, through the analysis of 373 scats collected during the austral summers of 2004/2005 and 2005/2006. The most frequent prey were three introduced mammals (house mice Mus musculus, ship rats Rattus rattus and rabbits Sylvilagus sp.) and the thin-billed prion Pachyptila belcheri (each season present on ca. $21 \%$ of the analysed scats). These represent the first systematic data on feral cat diet for the Falklands. A simple bioenergetics model suggests that cats could be eating in the region of 1,500-11,000 prions per season, representing $<1 \%$ of the local adult and subadult population. Predation on other seabirds nesting on New Island (several penguin species, albatrosses and cormorants) was unimportant, with the possible exception of white-chinned petrels Procellaria aequinoctialis, which nest locally in very small numbers. For each prion eaten, cats were estimated to have killed 1.1-1.9 ship rats during the summer season, and probably more in autumn and winter. Knowing that ship rats are prion predators, it is conceivable that, on the whole, cats are having a positive impact on the prion population, a scenario predicted by general theoretical models. Thus, considering the available information, we would not recommend the
\end{abstract}

\footnotetext{
R. Matias

Departamento Biologia Animal, Faculdade Ciências, Universidade de Lisboa, Ed. C2-3 piso,

1749-016 Lisbon, Portugal

P. Catry

Unidade de Investigação em Eco-Etologia, Instituto Superior de Psicologia Aplicada,

Rua Jardim do Tabaco 44, 1149-041 Lisbon, Portugal

R. Matias $\cdot$ P. Catry $(\bowtie)$

New Island Conservation Trust, New Island, Falkland Islands e-mail: paulo.catry@gmail.com
}

implementation of any eradication programme on New Island that would target cats in isolation. Nevertheless, it would be prudent to consider some local action targeting cats and rats around the small New Island white-chinned petrel colony.

Keywords Pachyptila belcheri - Procellaria $\cdot$ Predation · Invasive Species

\section{Introduction}

The introduction of mammalian predators on islands is regarded as one of the major threats to colonial seabirds of the recent past and the present (Moors and Atkinson 1984; Frenot et al. 2005). In particular, seabird populations have suffered high losses due to feral cat Felis catus predation (Schramm 1986; Fitzgerald et al. 1991; Keitt et al. 2002; Frenot et al. 2005), but small passerines and other birds are known to be affected too (see, e.g. Veitch 2001; McLennan et al. 1996). Such severe impacts result from lack of antipredatory adaptations of species that have evolved for longperiods in mammalian predator-free environments, such as oceanic islands (Powlesland et al. 1995; McLennan et al. 1996; Massaro and Blair 2003). Feral cats have been introduced on a wide range of sub-Antarctic islands (all lacking native terrestrial mammals; Bonner 1984), with catastrophic results in many cases (Frenot et al. 2005). Although the eradication of introduced mammals, including cats, in order to restore habitats is now a common measure adopted by managers of insular ecosystems (e.g. Nogales et al. 2004), the control of introduced pests should not be considered without a preliminary evaluation of the role of target species in the local food-webs. Cats, for example, can act as super-predators, removing undesirable animals, such as rodents or rabbits (Courchamp et al. 1999). Often, 
the whole community of introduced taxa cannot be easily removed at once; in such cases, it is advisable to carefully consider different management options, as the removal of only one member of the local community might have counterproductive effects (Courchamp et al. 1999; Zavaleta et al. 2001).

New Island, Falkland Islands, is an important bird area (Falklands Conservation 2006) because it holds internationally important seabird populations, including several globally threatened or near-threatened species, namely ca. 2 million pairs of thin-billed prions Pachyptila belcheri (Catry et al. 2003), which represent the largest known breeding colony in the entire world, over 10,000 pairs of black-browed albatrosses Thalassarche melanophrys (more than $1.5 \%$ of the world population), as well as several thousand pairs of rockhopper penguins Eudyptes chrysocome, Magellanic penguins Spheniscus magellanicus and king cormorants Phalacrocorax atriceps (I.J. Strange, unpublished). Furthermore, the island holds about half of the small Falkland Islands population of white-chinned petrels Procellaria aequinoctialis (Reid et al. 2007). These populations have coexisted with introduced cats, ship rats Rattus rattus, house mice Mus musculus and rabbits Sylvilagus sp., for, possibly, over a century, but it is unknown if any autochthonous species have suffered the effects of the presence of the alien mammals.

A recent study has shown that, on New Island, thinbilled prions can reproduce very successfully in the presence of the above-mentioned potential predators (Catry et al. 2007), but nothing is known on the prion adult mortality caused by cats, or the effects of cats on other species. In this paper, we present the first detailed assessment of feral cat diet anywhere in the Falklands and attempt to assess the direct and indirect impact of cats on their seabird prey.

\section{Materials and methods}

\section{Study area}

This study was carried out at New Island $\left(51^{\circ} 42^{\prime} \mathrm{S}\right.$, $61^{\circ} 17^{\prime} \mathrm{W}$ ), Falkland Islands, during the austral summers of 2004/2005 and 2005/2006. New Island covers an area of 1,970 ha. Until the end of 2006, it was managed as two independent properties (New Island South and New Island North), now united, each of them with approximately the same area. This study was conducted at New Island South nature reserve only, but, given the uniformity of habitat and seabird populations in the two former properties, the main conclusions should apply to the whole island. The main vegetation cover is dominated by short grasses (mainly the introduced Yorkshire fog Holcus lanatus), dwarf bushes (diddle-dee Empetrum rubrum, mountain berry Pernettya pumila, amongst others) and cushion plants (mostly Apiaceae). Taller grasses as tussock Parodiochloa flabellata and blue grass Poa alopecurus are restricted to isolated pockets. Another introduced species, the European gorse Ulex europaea, is present mostly around the settlement.

Cats are known to have been present on New Island from at least 1908 to 1916, when a whaling station operated there (I.J. Strange, personal communication). Around 1965, some 30 cats were brought by the then owner J. Davis, to the aim of exterminating thin-billed prions (I.J. Strange, personal communication). Presently, all cats living on New Island are wild and do not receive food or shelter from humans. Three other introduced mammals occur on the island. House mice Mus musculus were introduced accidentally, probably right after the arrival of the first settlers, in the late 1850 s or 1860 s. Ship rats Rattus rattus probably arrived at the time of the whaling station. Rabbits Sylvilagus sp. were most likely introduced around 1820 by whalers and sealers from North America (I.J. Strange). All three last species seem to occur throughout the island, although mice and rats may be more abundant in tussock covered areas and rabbits are particularly numerous around the settlement area.

Thin-billed prions have pelagic habits and are present on New Island only during the breeding season, the first birds arriving in early September and the last juveniles leaving in early March (Strange 1992); their breeding burrows are distributed all over the island surface in variable densities (Catry et al. 2003).

Diet sampling

Opportunist and systematic cat scat collection was made from November 2004 to mid February 2005 and again from September to December 2005 throughout New Island South. An effort was made to adequately sample all areas and habitats, so that results should not reflect the preferences of only a few individual cats or particular diet traits in some areas only. No other terrestrial carnivores exist on this island and therefore all scats found were known to be excreted by cats. Only a minor percentage of the collected scats $(<5 \%)$ seemed to be older than 1 month. Scats were soaked in water for ca. 20 min and prey items were sorted visually. Bones, teeth, hairs and feathers were identified through comparison with a small reference collection made for the purpose. Results are presented in terms of frequencies of occurrence. Although there can be spatial and seasonal variation in cat diet, preliminary analyses indicate such variation to be relatively unimportant. Given that sample sizes were small for each particular area and month, we opted not to present such detailed results in this paper and concentrate instead on the broad features of diet and possible impact on prey. 
Estimating the number of prions eaten per cat

We estimated the number of prions taken per cat using a simple bioenergetic model.

First, the daily energetic needs (or field metabolic rate, FMR as defined in Nagy 1987) of one adult cat were calculated from an allometric formula $(\mathrm{kJ} / \mathrm{day}=1.67$ ( $\mathrm{g}$ bodymass $)^{0.869}$; Eq. 5 in Nagy et al. 1999). As the average body mass of New Island cats is not known, we assumed it to be $4.0 \mathrm{~kg}$ for males and 3.5 for females (see Pascal and Castanet 1978); where differences between males and females were not to be taken into account, we used $3.75 \mathrm{~kg}$ for the body mass of an average cat.

Second, we reconstructed diet from scat analysis and determined the relative energetic importance of prions in overall cat energy intake (see more details in Tables 1,2). For this, we assumed the caloric value of fresh bird meat to be $10.9 \mathrm{~kJ} \mathrm{~g}^{-1}$ and of mammal meat to be of $6.25 \mathrm{~kJ} \mathrm{~g}^{-1}$ (following Phillips et al. 1999; Votier et al. 2004). Eggs were considered to have a caloric value of $29 \mathrm{~kJ} \mathrm{~g}^{-1}$ (dry weight), following Sotherland and Rahn (1987) and Votier et al. (2004). Energy content of each prey was determined using published values of average mass from various sources (see Table 2) and considering that the whole prey was ingested in each meal. For large prey that would represent more than one single meal (rabbits and waterfowl) we assumed the meal mass to equal the daily amount of fresh meat required by an average cat whenever there was only one prey type on one given scat. This amount (or daily fresh matter intake, FMI) was calculated using another allometric formula (Eq. 10 in Nagy 2001): $\mathrm{g} \mathrm{FMI} \mathrm{day}^{-1}=$ 0.348 (g bodymass) ${ }^{0.859}$, which yields, for a $3.75 \mathrm{~kg}$ cat, $409 \mathrm{~g} \mathrm{day}^{-1}$. However, on $44.8 \%$ of the scats where rabbits occurred, other prey species were also present; given the importance of rabbits on cat diet, on those cases we considered that the ingested rabbit mass would be better represented by half of the FMI. The "average ingested rabbit mass" per scat where rabbit occurred was therefore calculated using a weighed formula: $0.552 \mathrm{FMI}+0.448 \mathrm{FMI} / 2$, or $317.4 \mathrm{~g}$ for a $3.75 \mathrm{~kg}$ cat. As this is a likely source of uncertainty in the model (because the FMI represents an average daily value and because the size of the analyzed scats was quite variable, the amount of food taken daily by one cat was also probably not constant), and in order to test the sensitivity of the model, we also tentatively assumed the average rabbit meal mass to equal FMI or to be just half of this value (FMI/2). We assumed that both bird and mammal meals would include a similar percentage of nondigestible matter and therefore we used whole body mass values to calculate relative contributions of different prey.

Third we determined the approximate metabolizable energy content of one prion. The mass of one whole prion is $154 \mathrm{~g}$ (Cherel et al. 2002). We found that on prion corpses that had been obviously eaten by cats, the main parts consumed were the chest and the head. This is consistent with the most frequent body parts of prions present in scats: parts of the skull and bones from the chest. Based on these observations (and following Phillips et al. 1999; Votier et al. 2004) we considered that only $65 \%$ of one prion carcass (or $100 \mathrm{~g}$ ) would be available for cats as digestible matter. The metabolizable energy content of one prion was obtained multiplying assimilation efficiency (assumed to be $84 \%$ for this kind of food; see McVey et al. 1993 ) by its gross energy content, assuming that $1 \mathrm{~g}$ of prion fresh matter contains $10.9 \mathrm{~kJ}$ (following Phillips et al. 1999).

Knowing the metabolizable energy content of a prion and the relative energetic importance of prions in the overall diet, it is straightforward to estimate the number of prions consumed by each cat. Prions are regularly seen ashore for 5 months per year, and hence, daily consumption was multiplied by 30 and then by 5 to give the annual consumption per cat.

\section{Inclusion of female reproductive status in the model}

Energy requirements of pregnant and lactating females can be significantly different from the ones of non-pregnant females and males. Energy consumption of pregnant and lactating females has been described as 1.25 and 3.125 times, respectively, the energy requirements of nonpregnant females or adult males (see Konecny 1987). To account for a degree of uncertainty regarding the number of reproducing females, we modelled the total energy consumption considering two extreme situations: that one-third of the females were pregnant and that all females were pregnant. Pregnancy period was assumed to last 60 days followed by a lactation period of the same number of days. We used 1.25 and 3.125 times the calculated FMR for pregnant and lactating cats, respectively. On the absence of data on social structure of New Island feral cat population, a sex ratio of 1:1 was assumed.

\section{Estimating the number of cats}

During this study, we systematically searched for cats in an area of $0.5 \mathrm{~km}^{2}$ around the settlement area. All cats seen were noted and a detailed record with descriptions of individual variation in colour and morphology was kept. A density value was calculated and a tentative extrapolation was made for the rest of the island. Furthermore, when working in other parts of New Island South, during the whole summer, we kept detailed notes of cats seen, to produce a minimum estimate of the local population. This minimum estimate is given by the minimum number of identifiable cats. Furthermore, there were areas (more than $1 \mathrm{~km}$ from 
areas with recorded cats) where we saw no cats but noted abundant signs of their presence (fresh scats and footprints) and we assumed those sectors to have a minimum of one resident cat. These methods do not give us a precise and reliable estimate of the cat population, but they allow an estimation of a range of likely orders of magnitude.

White-chinned petrel breeding success

The breeding success of thin-billed prions on New Island in the presence of introduced predators has been assessed before (Catry et al. 2007). Other seabird species nesting on New Island are relatively abundant and given that they are absent from cat diet, or occur only very rarely (see "Results"), they seem not to be affected by this predator. One other species, however, is a cause for concern. Whitechinned petrels nest in very small numbers on New Island ( 36 pairs in 2004/2005 and 26 pairs in 2005/2006-Reid et al. 2007) and hence it is unrealistic to expect them to be found in any numbers on cat scats, even if predation occurred. Hence, we monitored breeding success of this species by visiting marked nests (inspected with the help of a burrowscope) in early December (just after egg laying) and again in late February (mid chick-rearing). Although a further, later, visit to the nests would have been desirable, that was not possible due to our absence from the island.

\section{Results}

Cat diet

A total of 373 scats found within the area of New Island South were analysed, of which 220 were collected on the austral summer of 2004/2005 and 153 during the austral summer of 2005/2006. On both seasons the most frequent prey were three introduced mammals (ship rats, house mice and rabbits) and the thin-billed prion (see Table 1). Other identified prey items were five bird species, eggs, insects and crustaceans (see Table 1 for details).
Table 1 Frequency of occurrence of each prey item and minimum number of sorted individuals in the analysed scat sample (in brackets the percentage of the total number of prey)
Insects were excluded from the calculation of the percentage of individual prey sorted, as they appeared mainly in one single scat

\begin{tabular}{|c|c|c|c|c|}
\hline \multirow[t]{4}{*}{ Prey items } & \multicolumn{4}{|c|}{ Austral summer } \\
\hline & \multicolumn{2}{|l|}{$2004 / 2005$} & \multicolumn{2}{|l|}{$2005 / 2006$} \\
\hline & \multicolumn{2}{|l|}{$N=220$ scats } & \multicolumn{2}{|l|}{$N=153$ scats } \\
\hline & $\begin{array}{l}\text { Frequency of } \\
\text { occurrence }\end{array}$ & $\begin{array}{l}\text { Number of } \\
\text { individuals }\end{array}$ & $\begin{array}{l}\text { Frequency of } \\
\text { occurrence }\end{array}$ & $\begin{array}{l}\text { Number of } \\
\text { individuals }\end{array}$ \\
\hline \multicolumn{5}{|l|}{ Mammals } \\
\hline Ship rat Rattus rattus & 37.3 & 97 (21.6) & 23.5 & $36(14.4)$ \\
\hline House mouse Mus musculus & 45.9 & $165(36.7)$ & 25.5 & $61(24.4)$ \\
\hline Rabbit Sylvilagus sp. & 32.7 & $72(16.0)$ & 59.5 & $91(36.4)$ \\
\hline Unidentified mammal (Rattus/Sylvilagus) & 0.0 & - & 3.3 & $5(2.0)$ \\
\hline \multicolumn{5}{|l|}{ Birds } \\
\hline Thin-billed prion Pachyptila belcheri & 21.8 & $52(11.6)$ & 20.9 & $32(12.8)$ \\
\hline Rockhopper penguin Eudyptes chrysocome & 1.4 & $3(0.7)$ & 0.0 & - \\
\hline Unidentified Anatidae & 1.8 & $4(0.9)$ & 1.3 & $2(0.8)$ \\
\hline Kelp goose Chloephaga hybrida & 0.5 & $1(0.2)$ & 0.0 & - \\
\hline Upland goose Chloephaga picta & 0.0 & - & 0.7 & $1(0.4)$ \\
\hline Austral thrush Turdus falklandii & 2.7 & $7(1.6)$ & 0.0 & - \\
\hline Long-tailed meadowlark Sturnella loyca & 1.4 & $3(0.7)$ & 0.0 & - \\
\hline Unidentified passerines & 5.9 & $13(2.9)$ & 2.0 & $3(1.2)$ \\
\hline Unidentified birds & 10.0 & $22(4.9)$ & 3.9 & $7(2.8)$ \\
\hline Egg & 5.0 & $11(2.4)$ & 7.8 & $12(4.8)$ \\
\hline Fish & 1.4 & - & 0.0 & - \\
\hline Insects (total) & 3.6 & - & 2.0 & - \\
\hline Curculionidae & 2.3 & 170 & 0.0 & - \\
\hline Carabidae & 0.5 & 1 & 0.0 & - \\
\hline Unidentified insects & 1.4 & 3 & 2.0 & 3 \\
\hline Crustacea (Decapoda) & 0.9 & - & 0.0 & - \\
\hline Cephalopoda & 2.7 & - & 0.0 & - \\
\hline Unidentified & 0.9 & - & 0.0 & - \\
\hline
\end{tabular}


Table 2 Mass constant values used on calculations and relative contribution of each type of prey in terms of fresh mass and energy on cat diet on each season

\begin{tabular}{llccc}
\hline & Meal fresh mass $(\mathrm{g})$ & \multicolumn{3}{l}{ Percentage of energy provided by each prey on diet } \\
\cline { 3 - 5 } & & $2004 / 2005$ & $2005 / 2006$ & Pooled \\
\hline Ship rat & $124(1)$ & 18.68 & 9.19 & 2.01 \\
House mouse & $16(2)$ & 4.10 & 59.41 & 3.20 \\
Rabbit & $317(3)$ & 35.47 & 2.27 & 45.77 \\
Rat/rabbit & $216(4)$ & 0.00 & 17.34 & 0.98 \\
Thin-billed prion & $154(5)$ & 21.75 & 0.00 & 20.02 \\
Rockhopper penguin & $120(6)$ & 0.98 & 2.94 & 0.56 \\
Unidentified Anatidae & $409(7)$ & 4.44 & 0.0 & 3.80 \\
Kelp goose & $409(7)$ & 1.11 & 1.47 & 0.63 \\
Upland goose & $409(7)$ & 0.0 & 0.0 & 0.63 \\
Austral thrush & $82.5(8)$ & 1.57 & 0.0 & 0.89 \\
Long-tailed meadowlark & $110(9)$ & 0.90 & 1.04 & 0.51 \\
Unidentified passerines & $96(10)$ & 3.39 & 2.91 & 2.38 \\
Unidentified birds & $115.5(11)$ & 6.90 & 1.02 & 5.18 \\
Egg & $31(12)$ & 0.71 & 0.85 \\
\hline
\end{tabular}

Caloric equivalents used were $10.9 \mathrm{~kJ} \mathrm{~g}^{-1}$ fresh mass for birds, $6.24 \mathrm{~kJ} \mathrm{~g}^{-1}$ fresh mass for mammals and $29 \mathrm{~kJ} \mathrm{~g}^{-1}$ (dry weight) for eggs. Mass values were taken from the following sources: (1) average mass for New Island individuals $(N=55)$; Mónica Silva, personal communication; (2) average value indicated by King et al. (1996) for New Zealand individuals; (3) the estimated average rabbit meal mass defined as 0.552FMI + 0.448FMI/2, FMI according to Nagy (2001); (4) average value between rat mass and rabbit meal mass; (5) Cherel et al. (2002); (6) estimated value from own experience according to size of the bill; (7) FMI according to Nagy (2001); (8) Trejo et al. (2006); (9) Jiménez and Jaksić (1989); (10) average mass of all identified passerines; (11) average mass of all identified passerines together with prions; (12) attending to shell structure and remaining membrane most if not all recorded eggs were from thin-billed prions; mass value from Strange (1980)

Number of cats

In both years of study, only two reproducing females were found in our intensive $0.5 \mathrm{~km}^{2}$ study plot. Each female (and their kittens) were observed on $>12$ occasions in each year and we find it most unlikely that other reproducing females could have been missed. One or two males were occasionally seen in each year and a possible female was seen once. These observations suggest a density of $8-10$ adult cats per $\mathrm{km}^{2}$, which is consistent with what has been found in other sub-Antarctic islands (Van Aarde 1984; Nogales et al. 2004), even though lower densities were recorded on the Kerguelen archipelago (Say et al. 2002). Knowing the density will be lower elsewhere on the island, because of less food and cover, we can somewhat speculatively estimate that the maximum likely overall density on New Island South is 8 cats per $\mathrm{km}^{2}$, which would mean a population of 80 adult cats. The absolute minimum, estimated from observations all over New Island South, is 16 cats, which is, undoubtedly, an underestimate. Given the above figures, it is reasonable to assume that the overall cat population on the $20 \mathrm{~km}^{2}$ of New Island is in the region of $30-160$ cats.

Number of prions consumed by cats

We calculated the daily energetic needs (FMR) of one average adult cat to be of $2,131 \mathrm{~kJ} \mathrm{day}^{-1}$. The energetic fraction of the diet provided by prion meat was estimated to be $21.75 \%$ in 2004/2005 and $17.74 \%$ in 2005/2006 (Table 2). As an average cat would require $63,925 \mathrm{~kJ}$ per month, prions would have contributed with 13,904 and $11,340 \mathrm{~kJ}$ per month, respectively, on each study year. Knowing that one whole prion provides ca. $916 \mathrm{~kJ}$ of metabolizable energy, each average cat might have taken 15.2 prions per month (and just under 76 per year) in 2004/2005 and 12.4 (or just under 62 per year) in 2005/2006 (note that predation only occurs during 5 months per year-see "Materials and methods").

If we assume the mass of rabbit meals to equal the FMI, each average cat would have eaten 69 prions on 2004/2005 and 53 on 2005/2006. Assuming that the mass of rabbit meals is FMI/2, instead of FMI (see "Materials and methods"), each cat would have eaten just under 90 prions on 2004/2005 and 82 on 2005/2006.

One pregnant female would consume $2,508 \mathrm{~kJ} \mathrm{day}^{-1}$ for 2 months (during that period some 36 prions would have been ingested in 2004/2005 and 29 prions in 2005/2006) and when lactating would require $6,271 \mathrm{~kJ} \mathrm{day}^{-1}$ for another 2 months (meaning the consumption of 89 prions in 2004/2005 and 73 prions in 2005/2006).

If we estimate the number of prions ingested by New Island cat population (30-160 individuals) assuming a proportion of one-third of all females to be pregnant and lactating during 2 months, some 2,616-13,952 prions 
would have been consumed during the breeding season of $2004 / 2005$ and $2,137-11,380$ prions in 2005/2006. If we consider the unlikely scenario of all females being pregnant then 3,295-17,574 prions would have been ingested in 2004/2005 and 2,688-14,334 in 2005/2006.

Breeding success of white-chinned petrels

In late February 2005, white-chinned petrel chicks were found in only 11 out of 23 nests known to have contained an egg; hence, breeding success was $48 \%$, or less. The corresponding figure for the following season was $44 \%$ (from 25 nests studied). In each year, we found half-grown feathers lying at the entrance of nests ( 3 cases in 2005 and 1 in 2006). The feathers had been chewed in a way that revealed the action of a mammal predator or scavenger.

\section{Discussion}

The results of this study show that, on New Island, the diet of feral cats during spring and summer consists mostly of introduced mammals, namely mice, rats and rabbits. The only native species regularly consumed is the thin-billed prion, which, on each study year, was found on approximately $21 \%$ of the analysed scats. These results are interesting and somewhat surprising, given that prions are extremely widespread and abundant. Our personal experience shows that, on most nights, even clumsy humans are able to catch prions by hand, without much effort. Cats are known to be opportunistic predators (taking prey approximately according to their availability and relative abundance, see for example Pontier et al. 2002). Nevertheless, on New Island it appears that cats frequently make an extra effort to hunt any of the fast-moving introduced mammals instead of taking the readily available and (by human standards) easy to catch prions. Although we do not have quantified data on the abundance of the mammalian prey, rabbits, for example, were clearly scarcer than prions. This seems to indicate some kind of preference for rodents and rabbits in relation to prions, although such a hypothesis needs a more careful formal testing. The relative importance that introduced mammals, including rats, has on the diet of feral cats on New Island can have important implications in relation to the role played by cats within the local food web (see below).

The estimated number of prions consumed by cats may seem high in absolute numbers. However, knowing that, according to the most recent census (Catry et al. 2003), there may be ca. 2 million pairs of prions on New Island (4 million adult birds plus many more immature nonbreeders), the percentage of birds killed by cats is quite small ( $<1 \%$ of the estimated breeding population) and may well be sustainable. In the absence of detailed demographic data, all that can be said is that prion-breeding success is high (Catry et al. 2007) and prions have co-existed with cats for many decades. Another aspect to consider is the fact that the toll taken by cats is small, compared with estimates of numbers taken by the two most important local native predators: striated caracaras (Phalcoboenus australis) and Falkland skuas (Catharacta antarctica) are estimated to take more than 40,000 adult and sub-adult prions each summer season (own unpublished data).

The main factor of uncertainty in our study relates to the number of cats living on New Island. Despite this, our models show that even when considering the scenario with the densest likely cat population, the number of prions consumed is relatively low, compared to what is taken by other predators or in relation to the size of the prey population. In this context, our estimates are useful and the first available for this globally important prion colony. Furthermore, results clearly show that cats do not regularly prey on other seabird species present on New Island, even though penguin, cormorant and albatross chicks are present in large numbers and probably could be easily subdued by a determined cat. Rockhopper penguin chicks were occasionally taken, but numbers involved were undoubtedly small. We cannot estimate such numbers, but only a reduced number of cats would have their vital areas overlapping with the localised penguin colonies. Rockhopper penguin breeding success was high in both study years and in two posterior breeding seasons (own unpublished data).

Because white-chinned petrels are so scarce on New Island, it is not surprising that the species was not found on cat scats. Nevertheless, cats could have an impact on this species, even by predating only a small number of individuals. Predation of adults is most unlikely, as it is risky for the cats. But we found evidence of possible cat predation on white-chinned petrel chicks in both study years. Despite this, our breeding success estimates (44-48\%) are at the same level as those obtained by studies at South Georgia, where figures for a mammal-free island were $44-50 \%$, in 3 years of study (Hall 1987; Berrow et al. 2000). It should be noted, however, that our final check of nests was midway through chick-rearing, and more chicks could have died before fledging. Hence, our breeding success values are maximum values. On the other hand, it must be pointed out that the New Island white-chinned population is known to have been approximately stable for the past 30 years (I.J. Strange, personal communication). More research is needed to better evaluate local breeding performance of this petrel and to confirm the role of cats (and eventually rats) as predators of chicks. Meanwhile, some precautionary measures to protect this colony should be considered (see below).

One of the most important results from our study is the indication that, during spring and summer, for each prion 
eaten, cats take approximately $1.1-1.7$ ship rats (see Table 1). Considering slightly higher rat consumption in autumn-winter (when other important prey items, such as prions and young rabbits, are unavailable), it is possible that, at least in some years, each cat directly eliminates more than five ship rats for each prion taken. Rats are potentially important small-petrel predators and they are known to eat prion chicks on New Island (Catry et al. 2007), but we have no data on the number of prions eaten by each rat. However, it can be easily seen that it would be enough for each rat to take two prion chicks per year, for cats, through predation on rats, to directly save a minimum of ca. ten prion chicks per season (in the absence of any compensatory mechanisms), per each adult prion killed. Under this speculative, but plausible, scenario, cats could have a positive effect on the prion population, despite the fact that they regularly hunt and kill these small petrels. The predation of cats on rabbits may also have a positive effect on the island ecosystem. In fact, rabbits, if present in large numbers, may have direct impact on seabirds by occupying their breeding burrows or destroying them during their digging activities; they may also contribute to soil erosion, which in turn will result on a reduction of quality of breeding habitat for burrowing petrels.

To conclude, the present study concurs with previous empirical and theoretical evidence (see, e.g. Courchamp et al. 1999; Zavaleta et al. 2001; Fan et al. 2005; Frenot et al. 2005; Gaucel and Pontier 2005) suggesting that trophic relationships between cats and their native and introduced prey can be complex. Although the impacts ship rats, mice and rabbits have on the New Island ecosystem have not been fully quantified, it seems possible that cats, by limiting the numbers of their mammal prey, could play a positive role in the maintenance of local biodiversity. Thus, considering the available information, we would not recommend the implementation of any eradication programme on New Island that would target cats in isolation. Nevertheless, and while a more integrated eradication plan cannot be implemented, it might be prudent to consider further monitoring of the white-chinned petrel population, coupled with direct action targeting cats and rats around the small New Island colony, particularly during the nesting season. To this aim, the possibility of locally poisoning or trapping rats and cats should be evaluated (see Jouventin et al. 2003).

Acknowledgments The authors thank Ian Strange, for all his help and support and for creating the conditions for researchers to work on New Island. The New Island Conservation Trust, an NGO and charity, supported field studies on their New Island reserve, through the supply of research facilities, accommodation and subsistence. This study was financed by Fundação para a Ciência e Tecnologia (FCT-Portugal) as part of the Programa Plurianual (UI\&D 331/94) and by research grants Praxis XXI BPD/11631/02 and SFRH/BPD/30031/2006 to PC. Further support was received from the Foreign \& Commonwealth Office through an Overseas Territories Environment Programme (OTEP) grant (FAL 201), and from the Falkland Islands Government. Maria Strange and Shona Strange provided important logistical and moral support in the field and in Stanley. Miguel Lecoq helped checking white-chinned petrel nests. All work was approved by the Falkland Islands Government (Environmental Planning Office).

\section{References}

Berrow SD, Croxall JP, Grant SD (2000) Status of white-chinned petrels Procellaria aequinoctialis Linnaeus 1758, at Bird Island, South Georgia. Antarct Sci 12:399-405

Bonner WN (1984) Introduced mammals. In: Laws RM (ed) Antarctic ecology 1. Academic, London, pp 237-278

Catry P, Campos A, Segurado P, Silva M, Strange I (2003) Population census and nesting habitat selection of thin-billed prion Pachyptila belcheri on New Island, Falkland Islands. Polar Biol 26:202-207

Catry P, Silva MC, MacKay S, Campos A, Masello J, Quillfeldt P, Strange IJ (2007) Can thin-billed prions Pachyptila belcheri breed successfully on an island with introduced rats, mice and cats? The case of New Island, Falkland Islands. Polar Biol 30:391-394. doi:10.1007/s00300-006-0204-8

Cherel Y, Bocher P, De Broyer C, Hobson KA (2002) Food and feeding ecology of the sympatric thinbilled Pachyptila belcheri and Antarctic P. desolata prions at Iles Kerguelen, Southern Indian Ocean. Mar Ecol Prog Ser 228:263-281

Courchamp F, Langlais M, Sugihara G (1999) Cats protecting birds: modelling the mesopredator release effect. J Anim Ecol 68:282-292

Falklands Conservation (2006) Important bird areas of the Falkland Islands. Falklands Conservation, Stanley

Fan M, Kuang Y, Feng Z (2005) Cats protecting birds revisited. Bull Math Biol 67:1081-1106

Fitzgerald BM, Karl BJ, Veitch CR (1991) The diet of feral cats (Felis catus) on Raoul Island, Kermadec Group. N Z J Ecol 15(2):123-129

Frenot Y, Chown SL, Whinam J, Selkirk PM, Convey P, Skotnicki M, Bergstrom DM (2005) Biological invasions in the Antarctic: extent, impacts and implications. Biol Rev 80:45-72

Gaucel S, Pontier D (2005) How predator food preference can change the destiny of native prey in predator-prey systems. Biol Invasions 7:795-806

Hall AJ (1987) The breeding biology of the white-chinned petrel Procellaria aequinoctialis at South Georgia. J Zool Lond 212:605-617

Jiménez JE, Jaksić FM (1989) Behavioral ecology of Grey EagleBuzzards, Geranoaetus melanoleucus, in central Chile. Condor 91:913-921

Jouventin P, Bried J, Micol T (2003) Insular bird populations can be saved from rats: a long-term experimental study of white-chinned petrels Procellaria aequinoctialis on Ile de la Possession (Crozet archipelago). Polar Biol 26:371-378

Keitt BS, Wilcox C, Tershy BR, Croll DA, Donlan CJ (2002) The effect of feral cats on the population viability of black-vented shearwaters (Puffinus opisthomelas) on Natividad Island, Mexico. Anim Conserv 5:217-223

King CM, Innes JG, Flux M, Kimberley MO (1996) Population biology of small mammals in Pureora Forest Park: 2. the feral house mouse (Mus musculus). N Z J Ecol 20:253-269

Konecny MJ (1987) Food habits and energetics of feral house cats in the Galápagos Islands. Oikos 50:24-32

Massaro M, Blair D (2003) Comparison of population numbers of yellow-eyed penguins, Megadyptes antipodes, on Stewart Island and on adjacent cat-free islands. N Z J Ecol 27:107-113 
McLennan JA, Potter MA, Robertson HA, Wake GC, Colbourne R, Dew L, Joyce L, McCann AJ, Miles J, Miller PJ, Reid J (1996) Role of predation in the decline of kiwi, Apterix spp., in New Zealand. N Z J Ecol 20:27-35

McVey M, Hall K, Trenham P, Soast A, Frymier L, Hirst A (1993) Wildlife exposure factors handbook, vol I. US Environmental Protection Agency, Washington, EPA report no. EPA/600/R-93/187

Moors PJ, Atkinson IAE (1984) Predation on seabirds by introduced animals, and factors affecting its severity. In: Croxall JP, Evans PGH, Schreiber RW (eds) Status and conservation of the world's seabirds. ICBP Tech. Publ. 2, Cambridge, pp 667-690

Nagy KA (1987) Field metabolic rate and food requirement scaling in mammals and birds. Ecol Monogr 57:111-128

Nagy KA (2001) Food requirements of wild animals: predictive equations for free-living mammals, reptiles, and birds. Nutr Abstr Rev Ser B 71:21R-31R

Nagy KA, Girard IA, Brown TK (1999) Energetics of free-ranging mammals, reptiles, and birds. Annu Rev Nutr 19:247-277

Nogales M, Martí A, Tershy BR, Donlan CJ, Veitch D, Puerta N, Wood B, Alonso J (2004) A review of feral cat eradication on islands. Conserv Biol 18:310-319

Pascal M, Castanet J (1978) Méthode de détermination de l'âge chez le Chat haret de les îles Kerguelen. Terre Vie 32:529-555

Phillips RA, Thompson DR, Hamer KC (1999) The impact of great skua predation on seabird populations at St Kilda: a bioenergetics model. J Appl Ecol 36:218-232

Pontier D, Say L, Debias F, Bried J, Thioulouse J, Micol T, Natoli E (2002) The diet of feral cats (Felis catus L.) at five sites on the Grande Terre, Kerguelen archipelago. Polar Biol 25:833-837

Powlesland RG, Roberts A, Lloyd BD, Merton DV (1995) Number, fate, and distribution of kakapo (Strigops habroptilus) found on Stewart Island, New Zealand, 1979-92. N Z J Zool 22:239_ 248

Reid T, Lecoq M, Catry P (2007) The white-chinned petrel Procellaria aequinoctialis population of the Falkland Islands. Mar Ornithol (in press)

Say L, Gaillard JM, Pontier D (2002) Spatio-temporal variation in cat population size in a sub-Antarctic environment. Polar Biol 25:90-95

Schramm M (1986) Burrow densities and nest site preferences of petrels (Procellariidae) at the Prince Edwards Islands. Polar Biol 6:63-70

Sotherland PR, Rahn H (1987) On the composition of bird eggs. Condor 89:48-65

Strange IJ (1980) The thin-billed prion Pachyptila belcheri at New Island, Falkland Islands. Gerfaut 70:411-445

Strange IJ (1992) A field guide to the wildlife of the Falkland Islands and South Georgia. HarperCollins, London

Trejo A, Ojeda V, Kun M, Seijas S (2006) Prey of White-throated Hawks (Buteo albigula) in the southern temperate forest of Argentina. J Field Ornithol 77(1):13-17

Van Aarde RJ (1984) Population biology and the control of feral cats on Marion Island. Acta Zool Fenn 172:107-110

Veitch CR (2001) The eradication of feral cats (Felis catus) from Little Barrier Island, New Zealand. N Z J Zool 28:1-12

Votier SC, Bearhop S, Ratcliffe N, Phillips RA, Furness RW (2004) Predation by great skuas at a large Shetland seabird colony. J Appl Ecol 41:1117-1128

Zavaleta ES, Hobbs RJ, Mooney HA (2001) Viewing invasive species removal in a whole-ecosystem context. Trends Ecol Evol 16(8):454-459 